\title{
Nanotechnology: an Emerging Hope in Crop Improvement
}

\author{
Anuron Banerjee 2(D), Anik Sarkar ${ }^{1}$ (D), Krishnendu Acharya ${ }^{2}$ (D) , Nilanjan Chakraborty 1,2,*(D) \\ 1 Molecular and Applied Mycology and Plant Pathology Laboratory, Department of Botany, University of Calcutta, Kolkata \\ $-700019$ \\ 2 Department of Botany, Scottish Church College, Kolkata 700006, India \\ * Correspondence: nilanjanchak85@gmail.com (N.C.);
}

Scopus Author ID 42761171800

Received: 21.02.2021; Revised: 21.04.2021; Accepted: 25.04.2021; Published: 9.05.2021

\begin{abstract}
The application of nanotechnology in the field of agriculture completely changed the present farming practices. One of the emerging challenges in the current agricultural system is developing disease resistance and increased productivity without accumulating environmental pollutants. Most of the applied conventional chemical fertilizers and pesticides have several side effects on both plants and the environment. Nanotechnology-based crop protection strategies have the potential to induce disease tolerance and enhancement of crop yield. Benefits of using nanoparticles in the agricultural fields include reducing environmental pollutants, rapid disease diagnosis, simple preparation process, less toxicity, and cost-effectiveness. Green synthesis of nanoparticles using plant extracts gained special attention as it is reproducible, biodegradable, and very effective against several plant pathogenic microbes. In the present review, we have discussed how different nanoparticles are being used to induce disease tolerance in crops, different types of nanoparticles, synthesis and characterization, uptake, and translocation process in plants. The molecular approaches of disease management using nanoparticles and the application of nanobiosensors are also enlightened in this review.
\end{abstract}

Keywords: carbon nanotubes; crop protection; green synthesis; nanobiosensors; nanoinsecticides; nanoparticles.

(C) 2021 by the authors. This article is an open-access article distributed under the terms and conditions of the Creative Commons Attribution (CC BY) license (https://creativecommons.org/licenses/by/4.0/).

\section{Introduction}

In recent years, agriculture and farming systems are more concerned about sustainable production and development of new disease-resistant varieties of crop plants. Though the first green revolution aimed to introduce high-yielding rice and wheat varieties, the whole world is awaiting the second green revolution as the current agricultural sectors face some new challenges. During the last several years, scientists have developed various new innovative technologies and strategies in agriculture. Many conventional methods are available for producing disease-resistant crops, but sometimes these methods fail to meet the actual need; thus, scientists search for new and convenient technologies that can overcome present agriculture-related problems. In this regard, the use of nanoparticles has appeared as a reliable solution for farmers. It is a new tool for agricultural research that mainly focused on plant disease diagnosis, high yield, and the development of new disease-resistant varieties. Nanotechnology is gaining much attention day by day due to its multidimensional use in various fields, including plant pathology [1]. Nanoparticles, typically ranging from 1 to 100 $\mathrm{nm}$, have performed various biological activities. It is more efficient than its molecular and 
macro-scale counterpart due to its unique physicochemical properties like the small size and large surface area to volume ratio, high reactivity, changed molecular interactions, etc. [2]. Macromolecules retain constant physical and chemical properties, but in the case of nanomaterials, the physical, chemical, and biological properties differ markedly from that of bulk materials and bridge the gap between the bulk material and nanomaterial [3]. Phytonanotechnology is the application of nanotechnology in plant science and is focused on the production of smart crops.

Nanoparticles can be divided into different types and categories based on their properties and materials from which they are made, but currently, in plant systems, nanoparticles of metalloids, metallic oxides, non-metals, carbon nanomaterials, quantum dots, liposomes, dendrimers have been used [4]. There are mainly three methods available for synthesizing nanoparticles physical, chemical, and biological methods. These methods are broadly categorized under two approaches, namely bottom-up synthesis and top-down synthesis. In bottom-up approaches, initially, small nanostructures are made, which are ultimately assembled into nanoparticles, and in top-down approaches, small nanoparticles are made from a macromolecular starting material [5,6]. Green synthesis of nanoparticles using plants and other microorganisms has gained special interest among scientists since it is costeffective, simple, and eco-friendly. Biologically synthesized nanoparticles are a promising tool for developing nanofertilizer, nanoinsecticide, nanopesticides. Besides, it minimizes the production of toxic environmental pollutants from the agricultural field and biodegradable [7,8]. For example, Medicago sativa were used for making gold nanoparticles and Rhynchotechum ellipticum used for formulating silver nanoparticle $[9,10]$.

Nanotechnology offers a new agrochemical tool that assists in high crop productivity reduction of toxic chemicals, plant-pathogen controls, and plant adaptation which confers crop protection (Figure 1).

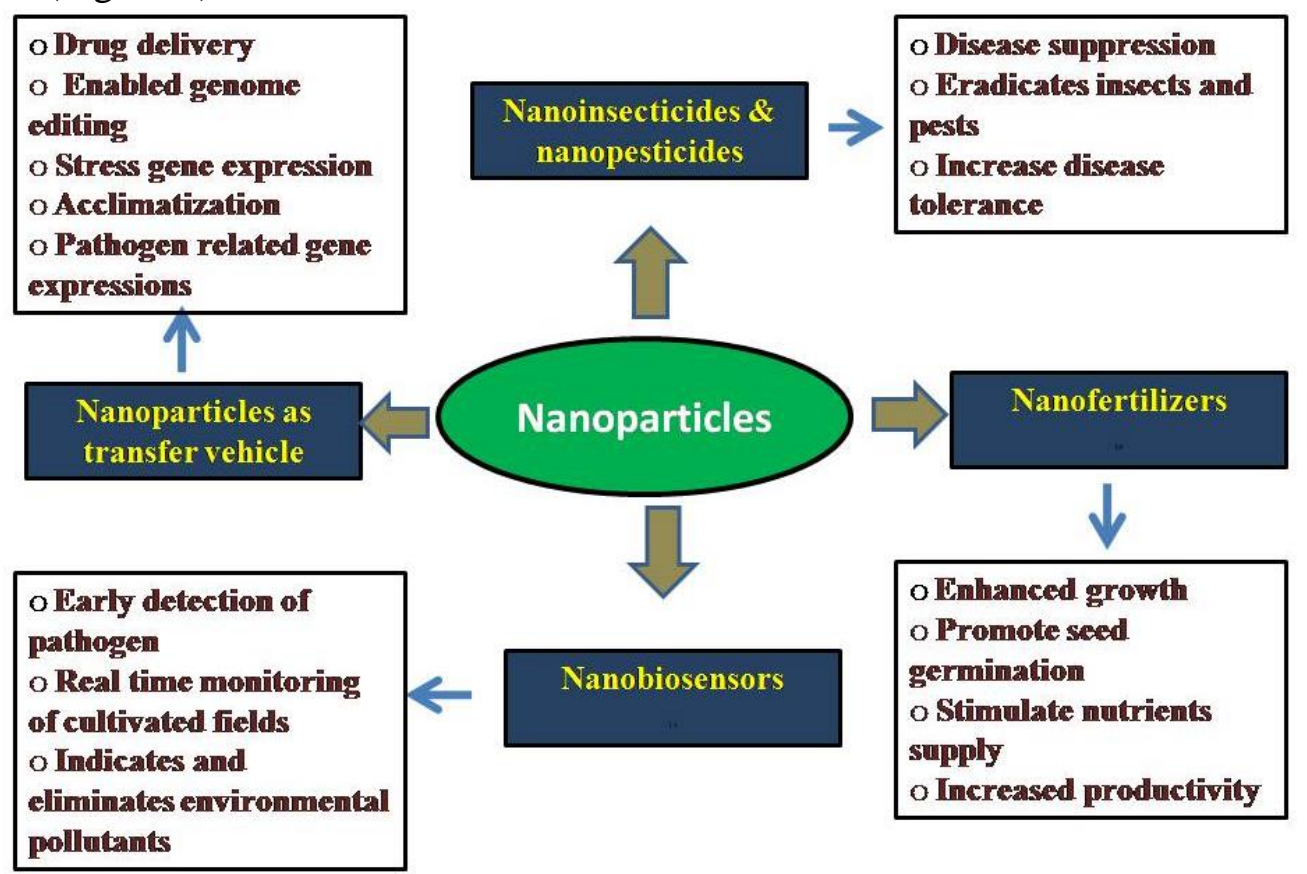

Figure 1. Different application of nanoparticles in crop protection.

The application of nanomaterials in crop protection is mainly based on the two principles, either by genetic modification by transferring new proteins or genetic material (DNA or RNA) or detecting plant disease through nanosensors [6]. Nanoparticles are 
considered as the new vehicle for gene transfer. Nanocapsules, nanofibres, nanoparticles are used as the transfer devices that carry foreign DNA or gene sequence and effectively modify the target genes [11]. Nanosensor is another implementation of nanoparticles in agriculture, which helps quantify and monitor crop production, disease management, an environmental pollutant, toxicity, soil quality, pathogen interaction, and insect attacks [12-14]. A recent study found that chitosan nanoparticles enhanced systemic resistance and immune responses in plants [15]. Besides, essential nutrients can be supplemented effectively by using nanofertilizer and nanopesticides following the green synthesis process. This present review reflected different nanoparticles mediated crop protection strategies, green synthesis of nanoparticles, and how nanoparticles interact and translate into plants. Also, the application of nanobiosensors in disease diagnosis and nanotechnology-based genetic engineering is discussed in this review.

\section{Types, Synthesis, and Characterization of Nanoparticles used in Plants}

Nanoparticles are small molecules or structures typically ranging from 1 to $100 \mathrm{~nm}$. They are more efficient, more reactive, more accurate, and more functionally active than their bulk counterpart [16]. Norio Taniguchi, from Tokyo, Japan, was the first who presented a scientific definition of the term nanotechnology. It is the study of matter on the atomic or molecular scale [17]. At present various types of nanoparticles are known to occur. Different parameters are considered for the classification of nanoparticles, such as functionalization, surface morphology, chemical nature, physicochemical properties, dimension, origin and source, magnetic properties, crystallinity, etc. [18]. In plants, metals and metallic oxides nanoparticles are used extensively.

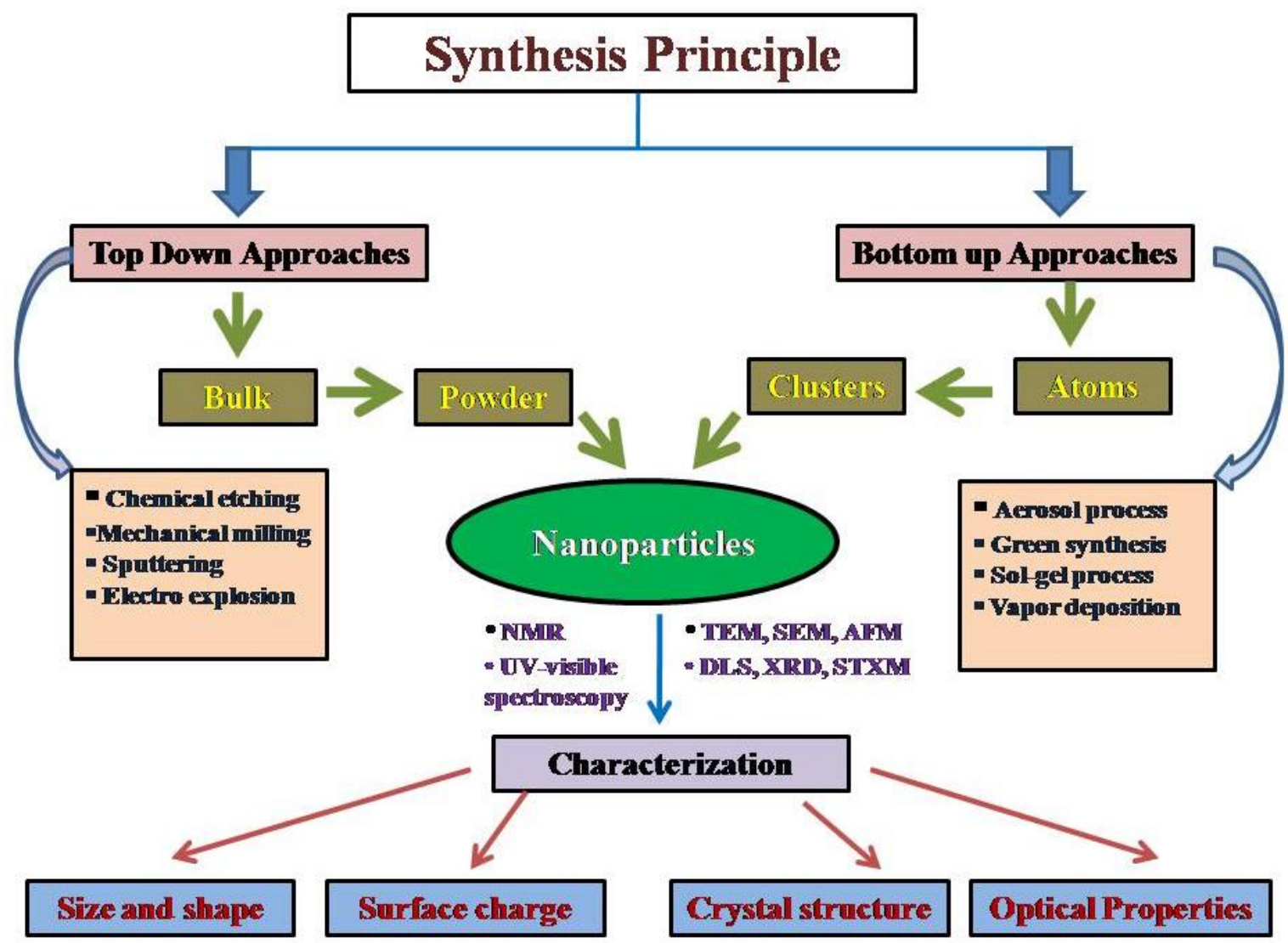

Figure 2.Different Approaches of nanoparticle synthesis and their characterization. 
Nanoparticles can be synthesized by physical, chemical, and biological (green synthesis) methods that fall under two fundamental principles: the top-down approach and the bottom-up approach (Figure 2). The former involves reducing macro scale or bulk materials into very small-sized particles $(1-100 \mathrm{~nm})$ through physical and chemical methods. Different techniques like mechanical milling, etching, sputtering, electro-explosion and laser ablation are incorporated to reduce the atom size in a top-down approach. The bottom-up principle includes the synthesis of green nanoparticles using biological organisms and plants. In this process, very small atoms are assembled into nanoparticles, and different techniques like chemical vapor deposition, laser pyrolysis, and atomic condensation are involved. Different reaction conditions like chemical concentrations, reaction time, temperature, and $\mathrm{pH}$ can modulate nanoparticles' physical properties. Thus by changing these conditions, anyone can design their desired nanomaterial $[5,19]$.

After synthesis of the nanoparticles, characterization is required before application to ensure its efficacy. For characterization, precise and credible protocols are needed. A wide range of techniques is involved for characterizing the size, shape, crystal structure, atomic composition, surface charge, and several other physical, chemical, and biological properties of the synthesized nanomaterials. Advanced microscopy techniques such as scanning electron microscopy (SEM), transmission electron microscopy (TEM), atomic force microscopy (AFM), X-Ray fluorescence microscopy (XFM), and scanning transmission X-Ray microscopy (STXM) are used to determine the size and morphology of the nanoparticles $[2,20,21]$. Brownian movement of nanoparticles in a colloidal suspension is characterized by using the dynamic light scattering (DLS) technique. The electrostatic interaction of nanoparticles with bioactive compounds depends on the surface charge, and the zeta potential value can measure it. X-ray diffraction (XRD) is another important technique for nanoparticle characterization. XRD provides data about the crystalline structures of the nanoparticles. Nuclear magnetic resonance (NMR) is used to determine different structural attributes. UVvisible spectroscopy gives an idea about nanoparticles' optical properties by measuring the light reflected by the nanoparticles. It also evaluates the stability of nanoparticles in the colloidal suspension [22]. These are some common methods for characterization, but several other techniques are also followed, but the development of new, innovative, cost-effective, simple techniques is much needed as nanotechnology is rapidly gaining interest from different research fields.

\section{Different Types of Nanoparticles used to Target Crop Protection}

In this present era use of nanoparticles triggers the advancement of traditional agricultural practice by reducing toxic agricultural outputs and improving disease management of crop plants. In the field of plant pathology, different types of nanoparticles have been used to control a wide range of plant pathogens. This includes metals and metal oxides nanoparticles, non-metal nanoparticles, carbon nanoparticles, chitosan nanoparticles, liposomes, quantum dots, and dendrimers. Various researches have documented that these nanoparticles' application can control foliar, root, stem, and fruit pathogens [4,23]. Below we have briefly discussed some of the effective nanoparticles and their application in crop disease management.

Silver nanoparticle (Ag NP): Ag nanoparticle is the first incorporated in the agricultural field for controlling plant pathogens. It is the most studied,well-characterized, and well-known for its antimicrobial activities [5,24]. Many soil-borne pathogens like Phytophthora parasitica, Meloidogyne spp., Fusarium spp. have been suppressed by applying silver nanoparticles [4]. 
Ag NP is a potential tool for crop disease management as it supports a wide range of plant defense strategies, including increased lignin deposition in the vascular bundles [25]. When the mixture of Ag NP and silica was applied against the bacterial pathogen Pseudomonas syringae pv. tomato, 25\% disease resistance was found in Arabidopsis thaliana [26]. Another study has reported that green synthesized nano-Ag suppressed the disease progression by almost $70 \%$ in banana fruit against the pathogen Colletotrichum musae [27]. Use of double-stranded DNA directed Ag NP controlled bacterial pathogen Xanthomonas perforans, which cause bacterial spot disease in tomato plant [28]. The fungicide fluconazole mixed with Ag NP exhibited enhanced fungicidal activity against Cladosporium berbarum, Alternaria alternata and Fusarium oxysporum, the major fungal pathogen for various commercially important crops [29,30]. Besides, the application of Ag nanoparticles helps to control several other plant pathogens.

Zinc-nanoparticles (Zn NP): Zn NP has several plant disease management applications since it exhibited excellent antimicrobial activities. Several investigations on Zn NP have revealed that it is very effective against several plants pathogenic fungi, including Mucor plumbeus, Alternaria alternata, Fusarium oxysporum, Sclerotinia sclerotiorum, Rhizoctonia solani, and Rhizopus stolonifera [31-33]. Application of Zinckicide, a formulation of nano Zn, suppressed citrus canker disease caused by the pathogen Xanthomonas citri [34]. In addition, Zn NPs are used extensively to control various bacterial pathogens as well.

Copper-nanoparticles ( $\mathrm{Cu} \mathrm{NP}$ ): Having antimicrobial properties and excellent disease control potential, $\mathrm{Cu}$ NPs are the best choice for plant disease diagnosis. Fungicides formulated from $\mathrm{Cu}$ NPs can inhibit the progression of Phytophthora infestans in the tomato plants [35]. Nano $\mathrm{CuO}$ applications enhanced the synthesis of different defense-related enzymes, including polyphenol oxidase, in plants [36,37]. In another study, it was found that biologically synthesized Cu NPs using Streptomyces griseus can successfully suppress root rot disease of tea caused by the pathogen Poria hypolateritia [38]. Bordeaux mixture made out from $\mathrm{Cu} \mathrm{NP}$ can inhibit the nematodes Xiphinema index, which causes disease in grapes plant [4]. Application of nano $\mathrm{Cu}$ formulated pesticides and fertilizers enhance disease resistance in various plants.

Non-metal, metalloids, metallic oxides nanoparticles: Very little data are available that how non-metal, metalloids and metallic oxides affect plant disease management. Still, there are some reports which ensure the disease resistance potentials of these nanoparticles. Among nonmetal nanoparticles, nano $\mathrm{S}$ (sulfur) and nano Ti (titanium) are the most studied. Nano $\mathrm{S}$ is mostly used for formulating nano fungicides. It was found that the application of $\mathrm{S}$ nanoparticles can protect plants against Fusarium solani, F. oxysporum, Aspergillus niger, and Venturia inaequalis [39]. Due to the autocatalytic activities of nano $\mathrm{Ti}$, it is used as a potential antifungal agent [40]. Metalloid Si nanoparticles have several impacts on disease management. Application of nano Si with Ag inhibited powdery mildew [41]. Several scientific studies have revealed that $\mathrm{Si}$ has several impacts on plant disease management when used in ions [4]. Nano $\mathrm{MnO}$ is a metallic oxide nanoparticle to control wilt disease in eggplant and watermelons [42]. $\mathrm{CuO}, \mathrm{TiO}_{2}, \mathrm{Fe}_{2} \mathrm{O}_{3}$, and $\mathrm{MgO}$ are some other metallic oxide nanoparticles that are used in plant pathology.

Carbon nanoparticles: Nanoparticles made out of carbons have several unique physical properties and functions in different research fields. Till now, very little information is available on how these nanoparticles contribute to plant disease management. However, recent researchers have revealed that engineered carbon nanoparticles influence plant growth and can 
eradicate some plant pathogens. There are mainly three types of carbon nanoparticles used in disease management: fullerenes, graphene oxides, and carbon nanotubes. Graphene oxide can induce $95 \%$ disease resistance in Xanthomonas oryzae against bacterial pathogens [43]. Further studies reported that single-wall carbon nanotubes could inhibit the conidia formation of Fusarium graminearum and Fusarium poae [44].

Chitosan nanoparticles: Chitosan is a natural biopolymer having several biological activities. Recently chitosan nanoparticles are gaining more interest as it is less toxic, biodegradable and cost-effective. A recent study demonstrated that the use of chitosan nanoparticles induced disease resistance in the plant. It is a very useful vehicle for drug delivery and gene transfer as its preparation is very simple [45,46]. Application of chitosan nanoparticles induced disease resistance in the tea plant by elevating the defense-related enzymes such as polyphenol oxidase, phenylalanine ammonia-lyase, and $\beta$-1,3-glucanase [15]. In addition, chitosan nanoparticles can enhance plants' immune responses, indicating that it is a unique and potential therapeutic agent for plant disease management.

Dendrimers: Theyaretree-like nanoparticles are mainly used as vehicles for transferring chemicals or DNA to achieve disease resistance. Dendrimers facilitate transportation of disease inhibiting chemicals into those tissue generally where these chemicals fail to reach [4].

Liposomes: Liposomes are mainly used for crop irrigation treatment as they are very stable in water. It is made up of phospholipid bilayers and has a spherical structure forming a central hollow core. Liposomes ligated with different antimicrobial agents and other disease suppressing chemicals have a potential function in plant disease management $[47,48]$.

\section{Green Synthesis of Nanoparticles: an Eco-Friendly Approach}

Nanoparticles can be synthesized by following different methodologies. The green synthesis of nanoparticles using plant extract and other microorganisms has gained special attention. It is very easy to prepare and less toxic. A wide range of biological organisms like plants, bacteria, and fungi are used for synthesizing nanoparticles.

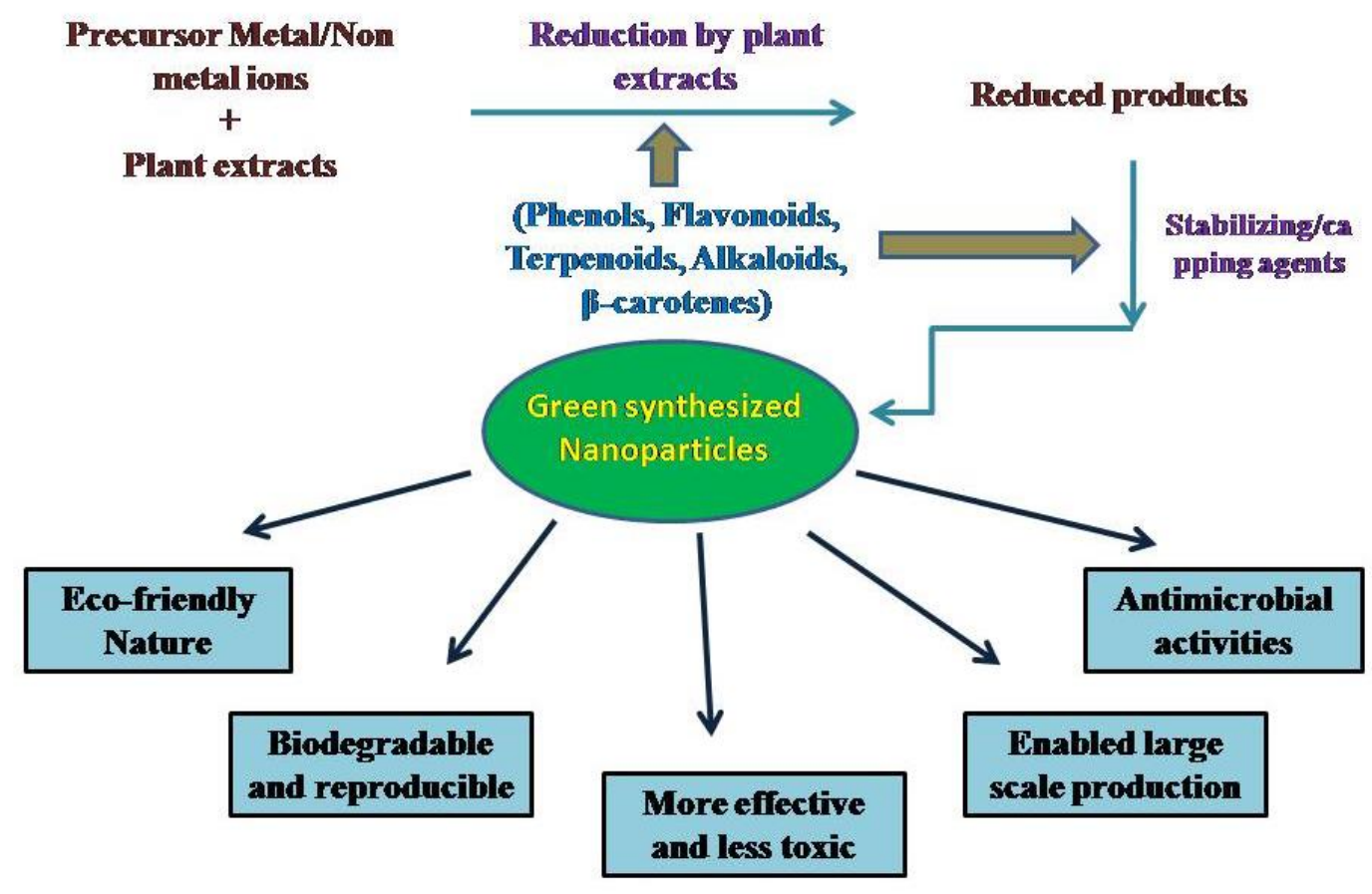

Figure 3. Green synthesis of nanoparticles using plant extracts. 
The green synthesis approach is concerned with reducing environmental pollutants, decreasing the production of harmful waste materials, and utilizing renewable stock materials. Among several biological sources, plant extracts are broadly utilized for producing metal and metal oxide nanoparticles. Plants are a rich source for several bioactive compounds like phenols, flavonoids, ascorbic acids, ketones, aldehydes, carboxylic acid, terpenoids, and amides. These compounds act as the reducing agents and stabilizers in the green synthesis of nanomaterials [19].

For the green synthesis of nanoparticles from plant leaf extract, the metal precursors are mixed with the leaf extract, and different reaction parameters like $\mathrm{pH}$, temperature, pressure, and solvent are set as optimum. The phytochemicals present in the leaf extract reduces the metal ions. One of the main benefits of using plant extracts in the green synthesis process is that the phytochemicals present in the plant extract function as reducing agents and stabilizing agents (Figure 3). Flavonoid acted as the reducing agent when green synthesis of silver nanoparticles is prepared using Ocimum basilicum leaf extract. Glucose and fructose are generally present in all plants. They are considered potential reducing agents for preparing metal nanoparticles $[49,50]$.

Different plant extracts are currently used for preparing nanoparticles. For preparing gold and silver nanoparticles Citrus limon, Azadirachta indica, and Avena sativa has been used. Different nanoparticles such as zinc, cobalt, copper, and nickel can be synthesized using Helianthus annus, Brassica juncea, and Medicago sativa [51]. A study found that when $\mathrm{CuO}$ nanoparticles are prepared using Malva sylvestris they exhibited potential antimicrobial activities against both gram-positive and gram-negative bacteria [52]. $\mathrm{ZnO}$ nanoparticles have been prepared by using tea leaf and china rose plant extract. Besides plants, several other biological organisms like bacteria, fungi, and algae are also used to produce different nanoparticles [19]. In the following Table 1, different green synthesized nanoparticles and their biological activities are presented.

Table 1. Green synthesis of nanoparticles using different biological organisms and plants.

\begin{tabular}{|c|c|c|c|c|}
\hline Nanoparticles & Precursor & $\begin{array}{l}\text { Plants extracts/Biological } \\
\text { organism }\end{array}$ & Application/ Bioactivity & Reference \\
\hline $\mathrm{Ag}$ & $\mathrm{AgNO}_{3}$ & Croton sparsiflorus & $\begin{array}{l}\text { Antimicrobial activities against } \\
\text { Escherichia coli and Bacillus } \\
\text { subtilis }\end{array}$ & [53] \\
\hline $\mathrm{Ag}$ & - & Acalypha indica & Used against soil-borne pathogens. & {$[54]$} \\
\hline $\mathrm{Ag}$ & $\mathrm{AgNO}_{3}$ & Olea europaea & Antimicrobial properties & {$[55]$} \\
\hline $\mathrm{Au}$ & $\mathrm{AuCl}$ & Syzygium aromaticum & Application in cancer treatment & [56] \\
\hline $\mathrm{CuO}$ & $\mathrm{CuSO}_{4}$ & Phyllanthus amarus & $\begin{array}{l}\text { Antimicrobial activities against } B \text {. } \\
\text { subtilis. }\end{array}$ & [57] \\
\hline $\mathrm{ZnO}$ & $\begin{array}{l}\mathrm{Zn}\left(\mathrm{O}_{2} \mathrm{CCH}_{3}\right)_{2}(\mathrm{H} \\
\left.{ }_{2} \mathrm{O}\right)_{2}\end{array}$ & Camellia sinensis & Used against microbes & {$[58]$} \\
\hline $\mathrm{Pd}$ & $\mathrm{Pd}(\mathrm{OAc})$ & Catharanthus roseus & Application in textile industry & [59] \\
\hline $\mathrm{Fe}_{2} \mathrm{O}_{3}$ & - & Medicago sativa & Used for drug delivery & [60] \\
\hline $\mathrm{TiO}_{2}$ & $\mathrm{TiO}_{2}(\mathrm{OH})_{2}$ & Oryza sativa & Photocatalyst activities & [61] \\
\hline $\mathrm{Ag}$ & - & Bacillus cereus & $\begin{array}{l}\text { Showed antimicrobial activities } \\
\text { against Staphylococcus aureus and } \\
\text { E. coli }\end{array}$ & {$[62]$} \\
\hline $\mathrm{Au}$ & - & $\begin{array}{l}\text { Rhodopseudomonas } \\
\text { capsulate }\end{array}$ & Used in cancer treatment & [63] \\
\hline $\mathrm{TiO}_{2}$ & $\mathrm{TiO}_{2}(\mathrm{OH})_{2}$ & Aspergillus flavus & $\begin{array}{l}\text { Used in the formulation of nano } \\
\text { fertilizer }\end{array}$ & [64] \\
\hline $\mathrm{Ag}$ & Agcl & Coriolus versicolor & Used for biolabling & {$[65]$} \\
\hline
\end{tabular}




\section{Effects of Nanoparticles in Crop Physiology and Disease Management}

The introduction of nanotechnology in the agricultural field has the potential to replace conventional farming approaches by developing some new tools that can be used to improve disease resistance in crops. The application of nanoparticles has direct effects on crop physiology through the use of nanofertilizer, which improves plants' ability to uptake nutrients. In addition, nanoparticles are a good choice for transferring genetic material or proteins that offer protection against plant pathogens by expressing pathogenesis-related genes. Nanosensor is another promising tool that can detect the presence of pathogens and also helps to eradicate waste environmental pollutants. Several investigations have revealed that huge losses have been caused in the agricultural field every year because of crop destruction by plant pathogens and pests. Evidence has shown that nanoparticles influence plants' physical and physiological state, which includes seed germination, enhances plant growth, and promotes stress tolerance [1].

The application of nanoparticles regulates plant growth, seed germination, and acclimatization. For example application of multi-walled carbon nanotubes (MWCNT) enhanced the biomass production in tomato plants and stimulate seed germination in barley, wheat, maize, and garlic [8,66,67]. It was found that $\mathrm{SiO}_{2}$ and $\mathrm{TiO}_{2}$ nanoparticles help in seed germination in different crop plants [5]. The exact mechanism of nanoparticle-mediated seed germination is not clear, but recent investigations have revealed that nanoparticles can penetrate the seed coat, facilitating nutrient and water absorption [68]. Applications of silver nanoparticles facilitate root initiation in cabbage and maize [69]. A study found that the application of $\mathrm{TiO}_{2}$ nanoparticles enhanced photosynthetic activity in spinach by elevating the level of protein and chlorophyll content in the leaf. The application of $\mathrm{TiO}_{2}$ nanoparticles in spinach also stimulates the activity of the Rubisco enzyme [70]. Similarly, Au nanoparticles affect plant height and the number of leaves associated with enhanced crop productivity [71]. When green synthesized $\mathrm{Zn}$ nanoparticles were applied on pearl millet, it increased protein and chlorophyll contents and also enhanced shoot growth and productivity [72]. Application of nano $\mathrm{Fe}_{3} \mathrm{O}_{4}$ on Ocimum basilicum enhanced carbohydrate, chlorophyll, protein, and essential oils [73]. Application of $\mathrm{ZnO}$ nanoparticles in peanut plant and chickpea plant influenced rootshoot growth, seed germination, and increased biomass production, respectively. $\mathrm{ZnO}$ nanoparticles stimulate seed germination in wheat [74,75].

Several methods are available to control various plant pathogens like viruses, fungi, bacteria, and insects that are responsible for major economic loss. Crop rotation, integrated pest management, genetic breeding, sanitation, and application of chemical pesticides are some of the methods that the farmers use to eradicate pathogens. In recent years the ability of nanoparticles to control plant disease is completely changing the present agricultural scenario. Modern researches have revealed that nanoparticles can combat plant pathogens and promote plant growth. Ag nanoparticles' application in ryegrass suppressed disease progression against pathogenic fungi by decreasing colony formation [5]. Several studies have reported that Ag nanoparticles' use eradicated several destructive crop pathogens, including Trichoderma viride, Candida albicans, and Phoma glomerata [8]. ZnO nanoparticles are effective against several fungal and bacterial pathogens, including Penicillium expansum, Mucor plumbens, Aspergillus flavus, and Pseudomonas aeruginosa [76-78]. Application of nano alumina was found to be effective against Rhyzopertha dominica, which is a destructive pest for stored food grains. It 
was also reported that alumina nanoparticles could control the rice weevil pest Sitiphilus oryzae [79].

Progressive climate changing is a challenging issue in agriculture. Changes in temperature, salinity, cold, environmental pollutant and alkalinity introduce different environmental stress conditions to the plants. To overcome these situations, plants need to choose smart adaptation strategies that include hormonal regulation, stress gene expression, and activation of different stress-related enzymes. Recent advancements in nanotechnology can induce stress tolerance in different crop species. The use of nanofertilizer helps overcome adverse environmental conditions in different plants [80], while the use of $\mathrm{SiO}_{2}$ nanoparticles improves salinity stress in tomato plants by accumulating proline [81]. Application of nano $\mathrm{ZnO}$ is associated with increased accumulation of proline and other amino acids, improves water deficiency, activation of antioxidants enzymes like superoxide dismutase (SOD), nitrate reductase, catalase, and peroxidase that improves stress tolerance in plants [82]. Different nanoparticles and their effects on crop physiology and disease management are presented in the following Table 2 .

Table 2. Different nanoparticles and their effects on crop protection.

\begin{tabular}{|c|c|c|c|c|}
\hline $\begin{array}{l}\text { Nanoparticles } \\
\text { (NP) }\end{array}$ & $\begin{array}{l}\text { Effective } \\
\text { concentrations }\end{array}$ & Crop species & Effects & Reference \\
\hline Ag NP & $75 \mathrm{mg} / \mathrm{L}$ & Triticum aestivum & $\begin{array}{l}\text { Induced seed germination, growth, } \\
\text { and improved heat stress }\end{array}$ & [83] \\
\hline Ag NP & $50-100 \mu \mathrm{g} / \mathrm{ml}$ & Vigna unguiculata & $\begin{array}{l}\text { Effective against Xanthomonas } \\
\text { campestris and } X \text {. axonopodis }\end{array}$ & [84] \\
\hline $\mathrm{ZnO} \mathrm{NP}$ & $1000 \mathrm{ppm}$ & Arachis hypogea & $\begin{array}{l}\text { Influenced root growth and high } \\
\text { yield. }\end{array}$ & [74] \\
\hline $\mathrm{ZnO} \mathrm{NP}$ & $20 \mathrm{mg} / \mathrm{L}$ & Triticum aestivum & Enhanced productivity & [85] \\
\hline $\mathrm{ZnO} \mathrm{NP}$ & $10 \mathrm{mg} / \mathrm{L}$ & Coffea arabica & $\begin{array}{l}\text { Promoted growth, biomass } \\
\text { accumulation and enhanced } \\
\text { photosynthetic activities. }\end{array}$ & [86] \\
\hline $\mathrm{CuO} \mathrm{NP}$ & $200 \mathrm{mg} / \mathrm{kg}$ & Spinacia oleracea & Enhanced biomass accumulation & [87] \\
\hline $\mathrm{CuO} \mathrm{NP}$ & $500 \mathrm{mg} / \mathrm{kg}$ & Triticum aestivum & Increased productivity & [88] \\
\hline MWCNT & $50 \mu \mathrm{g} / \mathrm{ml}$ & Zea mays, Hordeum vulgare & $\begin{array}{l}\text { Stimulate seed germination and } \\
\text { seedling growth }\end{array}$ & [89] \\
\hline MWCNT & $200 \mu \mathrm{g} / \mathrm{ml}$ & Lycopersicum esculantum & $\begin{array}{l}\text { Increased flower number and stem } \\
\text { growth }\end{array}$ & [90] \\
\hline $\mathrm{SiO}_{2} \mathrm{NP}$ & $2.5 \mathrm{mM} / \mathrm{L}$ & Oryza sativa & $\begin{array}{l}\text { Reduce heavy metal toxicity and } \\
\text { stimulates growth }\end{array}$ & {$[2]$} \\
\hline $\mathrm{Fe}_{2} \mathrm{O}_{3} \mathrm{NP}$ & $50 \mathrm{ppm}$ & Vigna radiata & Increased biomass accumulation & [91] \\
\hline $\mathrm{MgO} \mathrm{NP}$ & $7-10 \mu \mathrm{g} / \mathrm{ml}$ & Solanum lycopersicum & $\begin{array}{l}\text { Controlled bacterial pathogen } \\
\text { Ralstonia solanacearum causing } \\
\text { wilt disease. }\end{array}$ & [92] \\
\hline $\mathrm{Al}_{2} \mathrm{O}_{3} \mathrm{NP}$ & $400 \mathrm{mg} / \mathrm{L}$ & Solanum lycopersicum & $\begin{array}{l}\text { Suppressed Fusarium root rot } \\
\text { disease in tomato }\end{array}$ & [93] \\
\hline $\mathrm{TiO}_{2} \mathrm{NP}$ & $0.25 \%$ suspension & Spinacia oleracea & $\begin{array}{l}\text { Enhanced biomass accumulation, } \\
\text { chlorophyll and protein contents }\end{array}$ & [8] \\
\hline Ag NP & $100 \mu \mathrm{g} / \mathrm{ml}$ & Prunus domestica & $\begin{array}{l}\text { Controlled grey mold disease by } \\
\text { suppressing Botrytis cinerea }\end{array}$ & [94] \\
\hline
\end{tabular}

\section{Nanoparticles Mediated Gene Transfer and Crop Protection: a Molecular Approach}

The amalgamation of biotechnology with nanotechnology develops a new tool for gene transfer and drug delivery. Researchers have successfully manipulated gene expression by using nanofibers, nanocapsule, and nanoparticles [17]. The conventional gene transfer method using viral vectors faces several challenges during the transfer of genetic material. In comparison to viral vector-mediated genome delivery, nanotechnology-based gene transfer provides a more convenient approach. Moreover, it has been used for complete genome replacement in many plant species [95]. Application DNA coated Ag nanoparticles in addition 
to ethylene glycol successfully transferred plasmatic DNA into the isolated protoplast of the petunia plant [96]. CRISPR/Cas9 system is a revolutionary invention in molecular biology that changes the biotechnological practice forever. CRISPR/Cas9 is an RNA-mediated genome editing system that comprises two components, a small stretch of repeated sequence and Cas 9 protein. Transfer of CRISPR/Cas9 single guide RNA (sg-RNA) through nanotechnology opens a new era for plant disease management [97]. Application of nanoparticles in delivery of CRISPR/Cas9 system improves its specificity and efficiency for the target genome editing [98]. Chitosan is a natural biopolymer having several bioactivities, including antimicrobial properties against several pathogenic microbes. Chitosan nanoparticles are good choices for drug delivery and genome transfer as their transfection efficiency can be modified using various chemical agents such as polyethylene glycol (PEG). One of the benefits of using chitosan nanoparticles is that they can easily bind to RNA and can cross the plasma membrane, enabling their use as an excellent gene transfer vehicle. Chitosan nanoparticles can transfer siRNA, improving disease tolerance against various pests and pathogen in crop plants $[99,100]$. A study found that the application of chitosan nanoparticle enhanced defense-related gene expressions [15]. $\mathrm{SiO}_{2}$ nanoparticles mediated gene transfer has been carried out in Nicotiana tabacum and Zea mays which induced significant disease resistance [101]. Gene modification in various crops can be achieved using DNA-coated nanoparticles mediated gene gun technology [102]. In another study, genome editing has been done in Zea mays immature embryo by using mesoporous silica nanoparticles (MSNs). The MSNs are used to carry Cre recombinase which is correctly recombined in the chromosomal DNA by lox P in maize [103]. Recently a study was carried out where carbon nanotubes were used for si-RNA mediated gene silencing in Triticum aeativum, Nicotiana benthamiana, Gossypium hirsutm and Eruca sativa. Among which $95 \%$ si-RNA mediated gene silencing has been occurred in N. benthamiana [104].

\section{Understanding the Interaction and Translocation of Nanoparticles in Plants}

It is very important to understand how nanoparticles interact and are transported into the plants' different parts when applied. Generally, nanoparticles are taken up by different plants' vegetative parts like leaves, roots, and shoots. Natural openings like stomata, hydathode, stigma, and wounds are the pathway through which nanoparticles take entry [105]. However, to better understand the interaction between nanoparticles and plant surface, the plant's physiological and anatomical study is needed. Besides, these chemical and physical properties like size, shape, surface charge and stability also influence interaction and translocation in plants. The cuticle is a thick layer generally presented in the plant's upper surface vegetative organs. Most of the nanoparticles are inhibited by cuticles. However, in a study, it was found that $\mathrm{TiO}_{2}$ nanoparticles can able to make a hole in the cuticle layer [105]. For the internalization of the nanomaterials into the plant, delivery methods play a crucial role. In watermelon application of nanoparticles, in addition, to aerosol increased the internalization rate [106]. Plant root secreted mucilage and exudates in the rhizosphere area, which binds nanoparticles with the root surface and stimulates the internalization rate [107].

After penetration, the nanoparticles need to be translocated in all the plant tissue to achieve desired application results. In plants, nanoparticles are transported into the different parts by two pathways: viz symplastic translocation and apoplastic translocation. Through symplastic and apoplastic pathways, nanoparticles can move in the xylem and phloem tissue, ultimately transported in the whole plant body. For symplastic translocation, nanoparticles need 
to be penetrated inside the cell. Sometimes nanomaterials fail to enter the cell as the plant cell wall is made up of cellulose and hemicelluloses. However, it was reported that nanoparticles with a diameter ranging from 5 to $50 \mathrm{~nm}$ and carbon nanotubes could effectively cross cell walls in many plant species $[108,109]$. Apoplastic translocation facilitates the radial movement of nanoparticles into the root vascular tissue and helps in an upward movement of nanoparticles towards the aerial portion of the plants [105]. In ryegrass, TEM images are demonstrated that the cytoplasm and nuclei of the endodermal cells contained the nanoparticle, which is an apoplastic route of translocation [15]. Different size of nanoparticles is translocated through the plasmodesmata in rice, Arabidopsis and poplar plant. In another study, it was observed that $\mathrm{CeO}_{2}$ nanoparticles applied in the corn leaves fail to be translocated into the newly grown leaves in the same plant [110]. Sometimes translocation of nanoparticles depends upon the plant species in which it is applied. For instance, Phaseolus limensis fails to uptake $\mathrm{Fe}_{3} \mathrm{O}_{4}$ nanoparticles, but Cucurbita maxima can translocate $\mathrm{Fe}_{3} \mathrm{O}_{4}$ nanoparticles. Mungbean and wheat can effectively uptake and translocate $\mathrm{Cu}$ nanoparticles [111,112]. The effective translocation ability of these nanoparticles suggests that they can be used in the future for improving crop physiology and disease management.

\section{Nanopesticides and Nanoinsecticides}

In recent times, the agricultural system facing a major problem of different insect and pest attacks which lowers crop productivity and causing huge economic loss to the farmers. The application of conventional pesticides and insecticides has several adverse effects on the environment and crops due to their toxic nature. Most of the applied pesticides and insecticides are unable to block insect attacks due to their poor translocation ability. Moreover, chemical pesticides increase the expense of crop productivity and produce toxic byproducts and reduce soil biodiversity that is harmful to the plants and the soil-inhabiting microbes. To overcome this issue, agricultural research focuses more on producing a novel plant protection formulation with minimum side effects and greater activity. One such formulation is green synthesized nanoparticles that changed the entire scenario of plant protection strategies. Nanoparticles and the active ingredients of pesticides and insecticides offer a better crop protection strategy than conventional chemical agents. For instance, green synthesized Ag nanoparticles of Tinospora cordifolia exhibited potential insecticidal activity against the larvae of Culex quinquefasciatus and Anopheles subpictus [113]. The application of nanopesticides enhanced crop productivity by increasing the transport potential of the pesticides. It was observed that application nanocapsule with pyrethroid bifenthrin increased transport potential for different biofertilizers containing $\mathrm{Ca}^{2+}$ and $\mathrm{Mg}^{2+}$ cations [114]. Avermectin is a pesticide having a very short life span capacity and UV sensitivity. Application of porous Si nanoparticles along with Avermectin increases its stability and life span [11]. Besides, this application of nanopesticides and nanoinsecticides reduces the chemical dose and offers more positive results. Green synthesis of different metal nanoparticles using Azadirachta indica, Ocimum spp., Citrus limon leaf extracts, Accacia gum, and Punica granatum also known to have potential insecticidal and pesticidal activities [7].

\section{Nanobiosensors: a New Tool for Crop Disease Detection and Diagnosis}

One of the striking abilities of biological organisms is that they can detect and sense different environmental changes. The combination of biology and nanotechnology opens up a 
new wider prospect of disease detection and disease diagnosis process in crop plants. Rapid detection of the pathogen is needed before controlling the disease. Nanoparticles can be used for detecting compounds that could indicate the presence of pathogens. Besides this, nanobiosensors are tiny, stable, reproducible, accurate, and less toxic, which maximize sustainable agriculture. Basically, biosensors are made up of a signal receptor that receives signals from the surrounding environment and a signal transducer. Nanobiosensors are comprised of three components probe, bioreceptor, and transducer. When any change occurs in the environment, the receptor is received as a signal that includes a biomolecular interaction. A transducer measures the intensity of the signal and converts the information into an electrical signal in digital output. The use of nanosensors in the field can detect the presence of different crop pathogens, environmental pollutants, and soil nutrients [115]. Wireless nanosensors have been developed to detect insect attacks by sensing volatile organics secreted by pathogens in the crop plant [13]. It is very difficult to sense viruses and fungi present in very low amounts or when the pathogens' intensity is very less. The use of nano-based biosensors increased the sensitivity of pathogen detection and disease diagnosis in comparison to conventional ELISA techniques [4]. A report demonstrated that nanobiosensors had been designed to detect the presence of tobacco mosaic virus (TMV), lettuce mosaic virus, and cowpea mosaic virus $[116,117]$. Similarly, the beet necrotic yellow vein virus has been detected using quantum dot nanosensors in Polymyxa betae [118]. Recently, the use of portable nanodevices helps to detect different environmental pollutants, pathogens, insects, diseases, and chemicals; consequently, it decreases the use of pesticides, fungicides, and antibiotics [119]. Gold-based immunosensors havebeen used todetect karnal bunt disease in wheat [120]. In stress conditions plant accumulates several stress-related hormones. A study found that a gold electrode nanosensor and copper nanoparticles detected a plant pathogenic fungus by sensing salicylic acid concentrations in the soil [8].

Heavy metal pollution is a severe hazard in the agricultural field. Accumulation of heavy metals like $\mathrm{Pb}, \mathrm{Cd}, \mathrm{Hg}, \mathrm{Cu}$, and $\mathrm{Mn}$ causes severe bad effects on biodiversity [121]. Nanobiosensors can indicate the presence of such metals and can effectively remove these toxic metals providing environmental remediation. For instance, green synthesized Ag nanoparticles using mango leaves can sense the presence of $\mathrm{Hg}$ and $\mathrm{Pb}$ ions in the field [19]. Nanobiosensor combined with a global positioning system (GPS) was used for real-time monitoring of the agricultural field. This technology offers early detection of the pathogen and gives data about crop growth and environmental pollutants $[122,123]$. It can be concluded that the use of nanobiosensors supports sustainable agriculture by increasing crop yield and suppressing disease development.

\section{Nanophytotoxicity: a Negative Perspective of Nanoparticles Application}

The invention of nanotechnology changes the concept of disease management and disease diagnosis in plants. Plants are one of our ecosystem's main components, which plays a key role in maintaining environmental integrity. In some studies, it was found that sometimes application of nanoparticles causes adverse effects in plants. Most of the applied nanoparticles in the case of plants are metals nanoparticles, metal oxides nanoparticles, and carbon nanoparticles. In order to get positive results plants need to absorb these nanoparticles and translocation is also occurs throughout the plant body which could produce toxic byproduct in the plants and causes phytotoxicity. In a study, when MWCN, aluminum, alumina, zinc, and zinc oxides were applied in six plants radish, rape, rye grass, lettuce, corn, and cucumber to 
stimulate seed germination, phytotoxicity hasbeen reported in these plant species [124]. Application of cerium oxide nanoparticles in soybean plant reduced pod size and inhibited growth. It also hampered the nitrogen fixation ability of soybean plants [105]. Recent transcriptomics studies revealed that some metal nanoparticle suppressed pathogen and stressrelated gene expressions are essential for acclimatization [125]. Several studies have demonstrated that excess application of metal and metal oxides-based nanoparticles in the cultivated plants often results in an oxidative burst by interacting with the electron transport chain [105].

\section{Conclusions and Future Aspects}

During the last few decades, nanotechnology in the field of agriculture changed the whole agricultural practice forever. Rapid disease detection, disease diagnosis, nutrients enrichment, disease suppression, real-time monitoring of the cultivated fields, and environmental waste reduction are some of the aspects that are achieved by using nanoparticles in the agricultural fields. The main purposes of sustainable agriculture are reducing environmental pollutants and the increase in crop yield. In particular, nanotechnology is the best tool that triggers conventional farming towards sustainable agriculture. Advancement in nanotechnology offers a new green revolution in the future. The benefits and application of nanoparticles are vast. The success in disease management depends on how fast the pathogen can be detected. Detection of the pathogen before invading the plants is the optimum stage for controlling disease progression. Engineered nanoparticles, along with biosensors, developed a new tool for rapid pathogen detection. Besides, other applications of nanoparticles include antimicrobial activities that reduce contaminations, nanofertilizers that enhanced the nutrients levels, nanopesticides, and nanoinsecticides, nanobiosensors for early detection of the pathogens, nanoparticles-based genome editing. In addition, the green synthesis of nanoparticles using different biological organisms has gained a good research interest. The application of green synthesized nanoparticles lowers the risk of environmental pollution with increase efficiency of bioactivity. To better explore green synthesized nanoparticles, several practical trials in the field and greenhouse are under investigation. However, the practice of nanotechnology is still in the very early stage. More scientific and practical studies are required for further interpretation. Several studies and scientific reports demonstrated various nanoparticles' applications in plants, but there is a lack of information about why some plant species exhibited resistance against nanoparticles. Uptake and translocation of nanoparticles in plants are still not well explored. Interaction of nanoparticles with the plant surface is still a matter of question. Delivery of antimicrobial substances and genetic material via nanocapsules for improving disease resistance has gained more attention among researchers. The amalgamation of nanotechnology with biotechnology for developing new disease diagnostic tools will be a demanding topic in the near future. Though the present reviews enlightened the different applications of nanoparticles in crop protection and disease management, more investigations need to be carried out to stretch the application, techniques, and possibilities in plant pathology.

\section{Funding}

This research received no external funding. 


\section{Acknowledgments}

The authors declare no acknowledgments.

\section{Conflicts of Interest}

The authors declare no conflict of interest.

\section{References}

1. Mazzaglia, A.; Fortunati, E.;Kenny,J.M.; Torre,L.; Balestra, G.M. Nanomaterials in Plant Protection.In Nanotechnology in Agriculture and Food Science, 1sted.; Axelos, M.A., Voorde, M.V., Eds.; Wiley-VCH Verlag $\mathrm{GmbH} \quad \& \quad \mathrm{Co} \quad \mathrm{KGaA}$; Weinheim, Germany, 2017; 115-134, https://doi.org/10.1002/9783527697724.ch7.

2. Wang, P.; Lombi, E.; Zhao, F-J.; Kopittke, P.M. Nanotechnology: A New Opportunity in Plant Sciences. Trends Plant Sci. 2016, 21, 699-712, http://dx.doi.org/10.1016/j.tplants.2016.04.005.

3. Rajput, N. Methods of preparation of nanoparticles-A Review. IJAET.2015,7, 1806-1811.

4. Elmer, W.; White, J.C. The Future of Nanotechnology in Plant Pathology. Annu. Rev. Phytopathol. 2018, 56, 111-33, https://doi.org/10.1146/annurev-phyto-080417-050108.

5. Singh, A.; Singh, N.B.; Hussain, I.; Singh, H.; Singh, S.C. Plant-nanoparticle interaction: An approach to improve agricultural practices and plant productivity. Int. J. Pharm. Sci. Invent. 2015, 4, 25-40.

6. Khandelwal, A.; Joshi, R.Synthesis of Nanoparticles and their Application in Agriculture. Acta Sci. Agric. 2018, 2, 10-13.

7. Ghidan, A.Y.; Al-Antary, T.M.; Awwad, A.M. Aphidicidal potential of green synthesized magnesium hydroxide nanoparticles using Olea europaea leaves extract. ARPN J. Agric. Biol. Sci. 2017, 12, 293-301.

8. Shang, Y.; Hasan, K.M.; Ahammed, G.J.; Li, M.; Yin, H.; Zhou, J. Applications of Nanotechnology in Plant Growth and Crop Protection: A Review. Molecules 2019, 24, 2558, https://doi.org/10.3390/molecules24142558.

9. Hazarika, D.; Phukan, A.; Saikia, E.; Chetia, B. Phytochemical screening and synthesis of silver nanoparticles using leaf extract of Rhynchotechum ellipticum. Int J Pharm Pharm Sci. 2014, 6, 672-674.

10. Panpatte, D.G.; Jhala, Y.K.; Shelat, H.N.; Vyas, R.V. Nanoparticles: The next generation technology for sustainable agriculture. In Microbial Inoculants in Sustainable Agricultural Productivity; Springer, New Delhi, India, 2016; 289-300.

11. Ghormade, V.; Deshpande, M.V.; Paknikar, K.M. Perspectives for nano-biotechnology enabled protection and nutrition of plants. Biotechnol. Adv. 2011, 29, 792-803, https://doi.org/10.1016/j.biotechadv.2011.06.007.

12. Cheng, H.N.; Klasson, K.T.; Asakura, T.; Wu, Q. Nanotechnology in agriculture. In Nanotechnology: Delivering on the Promise Volume 2; Cheng, H.N., Doemeny, L., Geraci, C.L., Schmidt, D.G., Eds.; ACS: Washington, DC, USA, 2016; 233-242.

13. Afsharinejad, A.; Davy, A.; Jennings, B.; Brennan, C. Performance analysis of plant monitoring nanosensor networks at $\mathrm{THz}$ frequencies. IEEE Internet Things J. 2016, 3, 59-69, https://doi.org/10.1109/JIOT.2015.2463685.

14. El-Shanshoury, A.E.R.; Darwesh, O.M.; Sabae, S.Z.; Awadallah, O.A.; Hassan, S.H. Bio-manufacturing of selenium nanoparticles by Bacillus subtilis isolated from Qarun Lake and evaluation their activity for water remediation. Biointerface Res Appl Chem. 2020, 10, 5834-5842, https://doi.org/10.33263/BRIAC104.834842.

15. Chandra, S.; Chakraborty, N.; Dasgupta, A.; Sarkar, J. Panda, K.; Acharya, K. Chitosan nanoparticles: A positive modulator of innate immuneresponses in plants. Sci. Rep. 2015, 5, 15195, https://doi.org/10.1038/srep15195.

16. Sekhon, B.S. Nanotechnology in agri-food production: an overview. Nanotechnol. Sci. Appl.2014,7, 31-53, https://dx.doi.org/10.2147\%2FNSA.S39406.

17. Agrawal, S.; Rathore, P. Nanotechnology Pros and Cons to Agriculture: A Review Int. J. Curr. Microbiol. App. Sci. 2014, 3, 43-55, https://doi.org/10.13140/2.1.1648.1926. 
18. Ahmad, S.; Munir, S.; Zeb, N.; Ullah, A.; Khan, B.; Ali, J.; Bilal, M.; Omer, M.; Alamzeb, M.; Salman, S.M.; Ali, S. Green nanotechnology: a review on green synthesis of silver nanoparticles - an ecofriendly approach. Int. J. Nanomedicine, 2019, 14, 5087-5107, https://doi.org/10.2147/IJN.S200254.

19. Singh, J.; Dutta, T.; Kim, K-H.; Rawat, M.; Samddar, P.; Kumar, P. 'Green'synthesis of metals and their oxide nanoparticles: applications for environmental remediation. J Nanobiotechnol. 2018, 16, 84, https://doi.org/10.1186/s12951-018-0408-4.

20. Pal, S.L.; Jana, U.; Manna, P.K.; Mohanta, G.P.; Manavalan, R. Nanoparticle: An overview of preparation and characterization. J. Appl. Pharm. Sci. 2011, 01, 228-234.

21. Safenkova, I.V.; Zherdev, A.V.; Dzantiev, B.B. Using atomic force microscopy to assess surface modification of gold nanoparticles. Biointerface Res Appl Chem. 2019, 9, 3894-3897, https://doi.org/10.33263/BRIAC92.894897.

22. Mourdikoudis, S.; Pallares, R.M.; Thanh, N.T.K. Characterization techniques for nanoparticles: comparison and complementarity upon studying nanoparticle properties Nanoscale 2018, 10, 12871-12934, https://doi.org/10.1039/C8NR02278J.

23. Bayoumy, A.M.; Elhaes, H.; Osman, O.; Kholmurodov, K.T.; Hussein, T.; Ibrahim, M.A. Effect of nano metal oxides on heme molecule: molecular and biomolecular approaches. Biointerface Res. Appl Chem. 2020, 10, 4837-4845, https://doi.org/10.33263/BRIAC101.837845.

24. Keshvadi, M.; Karimi, F.; Valizadeh, S.; Valizadeh, A. Comparative study of antibacterial inhibitory effect of silver nanoparticles and garlic oil nanoemulsion with their combination. Biointerface Res Appl Chem. 2019, 9, 4560-4566, https://doi.org/10.33263/BRIAC96.560566.

25. Moussa, S.H.; Tayel, A.A.; Alsohim, A.S.; Abdallah, R.R. Botryticidal activity of nanosized silver-chitosan composite and its application for the control of gray mold in strawberry. J. Food Sci. 2013,78, 589-94, https://doi.org/10.1111/1750-3841.12247.

26. Chu, H.; Kim, H.J.; Kim, J.S.; Kim, M.S.; Yoon, B.D.; Park, H.J.; Kim, C.Y. A nanosized Ag-silica hybrid complex prepared by $\gamma$-irradiation activates the defense response in Arabidopsis. Radiat. Phys. Chem. 2012, 81, 180-184, https://doi.org/10.1016/j.radphyschem.2011.10.004.

27. Jagana, D.; Hegde, Y.R.; Lella, R. Green nanoparticles: a novel approach for the management of banana anthracnose caused by Colletotrichum musae. Int. J. Curr. Microbiol. Appl. Sci. 2017, 6, 1749-56, https://doi.org/10.20546/ijcmas.2017.610.211.

28. Ocsoy, I.; Paret, M.L.; Ocsoy, M.A.; Kunwar, S.; Chen, T.; You, M.; Tan, W. Nanotechnology in plant disease management: DNA-directed silver nanoparticles on graphene oxide as an antibacterial against Xanthomonasperforans. ACS Nano. 2013,7, 8972-8980, https://doi.org/10.1021/nn4034794.

29. Bholay, A.D.; Nalawade, P.M.; Borkhataria, B.V. Fungicides potential of biosynthesized silver nanoparticles against phytopathogens and potentiation of Fluconazol. World Res. J. Pharm. Res. 2013, 1, 12-15.

30. Fajar, M.N.; Endarko, E.; Rubiyanto, A.; Malek, N.A.N.N.; Hadibarata, T.; Syafiuddin, A. A green deposition method of silver nanoparticles on textiles and their antifungal activity. Biointerface Res Appl Chem. 2020, 10, 4902-4907, https://doi.org/10.33263/BRIAC101.902907.

31. He, L.; Liu, Y.; Mustapha, A.; Lin, M. Antifungal activity of zinc oxide nanoparticles against Botrytis cinerea and Penicillium expansum. Microbiol. Res. 2011, 166, 207-15, https://doi.org/10.1016/j.micres.2010.03.003.

32. Wani, A.H.; Shah, M.A. A unique and profound effect of $\mathrm{MgO}$ and $\mathrm{ZnO}$ nanoparticles on some plant pathogenic fungi. J. Appl. Pharm. Sci. 2012,2, 40-44.

33. Sardella, D.; Gatt, R.; Valdramidis, V.P. Physiological effects and mode of action of ZnO nanoparticles against postharvest fungal contaminants. Food Res. Int. 2017, 101, 274-279, https://doi.org/10.1016/j.foodres.2017.08.019.

34. Graham, J.H.; Johnson, E.G.; Myers, M.E.; Young, M.; Rajasekaran, P.; Das, S.; Santra, S. Potential of nanoformulated zinc oxide for control of citrus canker on grapefruit trees. Plant Dis. 2016, 100, 2442-47, https://doi.org/10.1094/pdis-05-16-0598-re.

35. Giannousi, K.; Avramidis, I.; Dendrinou-Samara, C. Synthesis, characterization and evaluation of copper based nanoparticles as agrochemicals against Phytophthora infestans. RSC Adv. 2013, 3, 21743-21752, https://doi.org/10.1039/C3RA42118J.

36. Wang, X.; Liu, X.; Han, H.Y. Evaluation of antibacterial effects of carbon nanomaterials against copperresistant Ralstonia solanacearum. Colloids Surf. B Biointerfaces. 2013, 103, 136-142, https://doi.org/10.1016/j.colsurfb.2012.09.044. 
37. Sarkar, J.; Chakraborty, N.; Chatterjee, A.; Bhattacharjee, A.; Dasgupta, D.; Acharya, K. Green Synthesized Copper Oxide Nanoparticles Ameliorate Defence and Antioxidant Enzymes in Lens culinaris.Nanomaterials. 2020, 10, 312-339, https://doi.org/10.3390/nano10020312.

38. Ponmurugan, P.; Manjukarunambika, K.; Elango, V.; Gnanamangai, B.M. Antifungal activity of biosynthesized copper nanoparticles evaluated against red root-rot disease in tea plants. J. Exp. Nanosci. 2016, 11, 1019-31, https://doi.org/10.1080/17458080.2016.1184766.

39. Rao, K.J.; Paria, S. Use of sulfur nanoparticles as a green pesticide on Fusarium solani and Venturia inaequalis phytopathogens. RSC Adv. 2013, 3, 10471-10478, https://doi.org/10.1039/C3RA40500A.

40. Boxi, S.S.; Mukherjee, K.; Paria, S. Ag doped hollow TiO2 nanoparticles as an effective green fungicide against Fusarium solani and Venturia inaequalis phytopathogens. Nanotechnology. 2016, 27, 085103, https://doi.org/10.1088/0957-4484/27/8/085103.

41. Park, H-J.; Kim, S.H.; Kim, H.J.; Choi, S-H. A new composition of nanosized silica-silver for control of various plant diseases. Plant Pathol. J. 2006, 22, 295-302, http://dx.doi.org/10.5423/PPJ.2006.22.3.295.

42. Elmer, W.H.; White, J. C. The use of metallic oxide nanoparticles to enhance growth of tomatoes and eggplants in disease infested soil or soilless mediaum. Environ. Sci. Nano. 2016, 3, 1072-1079, https://doi.org/10.1039/C6EN00146G.

43. Chen, J.; Wang, X.; Han, H. A new function of graphene oxide emerges: inactivating phytopathogenic bacterium, Xanthomonas oryzae pv. oryzae. J. Nanopart. Res. 2013, 15, 1-14, http://dx.doi.org/10.1007/s11051-013-1658-6.

44. Wang, X.; Liu, X.; Chen, J.; Han, H.; Yuan, Z. Evaluation and mechanism of antifungal effects of carbon nanomaterials in controlling plant fungal pathogen. Carbon. 2014, 68, 798-806, https://doi.org/10.1016/J.CARBON.2013.11.072.

45. El Hadrami, A.; Adam, L.R.; El Hadrami, I.; Daayf, F. Chitosan in plant protection. Mar. Drugs. 2010, 8, 968-987, https://dx.doi.org/10.3390\%2Fmd8040968.

46. Amanzadi, B.; Mirzaei, E.; Hassanzadeh, G.; Mahdaviani, P.; Boroumand, S.; Abdollahi, M.; Abdolghaffari, A.H.; Majidi, R.F. Chitosan-based layered nanofibers loaded with herbal extract as wound-dressing materials on wound model studies. Biointerface Res Appl Chem. 2019, 9, 3979-3986, https://doi.org/10.33263/BRIAC94.979986.

47. Matouskova, P.; Marova, I.; Bokrova, J.; Benesova, P. Effect of encapsulation on antimicrobial activity of herbal extracts with lysozyme. Food Technol. Biotechnol. 2016, 54, 304-316, https://doi.org/10.17113/ftb.54.03.16.4413.

48. Bahramian, G.; Golestan, L.; Khosravi-Darani, K. Antimicrobial and antioxidant effect of nanoliposomes containing Zataria multiflora boiss essential oil on the rainbow trout fillets during refrigeration. Biointerface Res Appl Chem. 2018, 8, 3505-3513.

49. Ahmad, N.; Sharma, S,; Alam, M.K.; Singh, V.N.; Shamsi, S.F.; Mehta, B.R.; Fatma, A. Rapid synthesis of silver nanoparticles using dried medicinal plant of basil. Colloids Surf B Biointerfaces. 2010, 81, 81-86, https://doi.org/10.1016/j.colsurfb.2010.06.029.

50. Chand, K.; Cao, D.; Fouad, D.E.; Shah, A.H.; Dayo, A.Q.; Zhu, K.; Lakhan, M.N.; Mehdi, G.; Dong, S. Green synthesis, characterization and photocatalytic application of silver nanoparticles synthesized by various plant extracts. Arab J. Chem.2020, 13, 8248-8261, https://doi.org/10.1016/j.arabjc.2020.01.009.

51. Marchiol, L. Synthesis of metal nanoparticles in living plants. Ital J Agron. 2012, 7, 274-82, http://dx.doi.org/10.4081/ija.2012.e37.

52. Awwad, A.M.; Albiss, B.A.; Salem, N.M. Antibacterial activity of synthesized copper oxide nanoparticles using Malva sylvestris leaf extract. SMU Med J. 2015, 2, 91-101.

53. Kathiravan, V.; Ravi, S.; Ashokkumar, S.; Velmurugan, S.; Elumalai, K.; Khatiwada, C.P. Green synthesis of silver nanoparticles using Croton sparsiflorus morong leaf extract and their antibacterial and antifungal activities, Spectrochim Acta A Mol Biomol Spectrosc. 2015, 139, 200-205, https://doi.org/10.1016/j.saa.2014.12.022.

54. Krishnaraj C, Jagan EG, Rajasekar S, Selvakumar, P.; Kalaichelvan, P.T.; Mohan, N. Synthesis of silver nanoparticles using Acalypha indica leaf extracts and its antibacterial activity against water borne pathogens. Colloids Surf B Biointerfaces. 2010, 76, 50-56, https://doi.org/10.1016/j.colsurfb.2009.10.008.

55. Khalil, M.M.H.; Ismail, E.H.; Baghdady, K.Z.E.; Mohamed, D. Green synthesis of silver nanoparticles using olive leaf extract and its antibacterial activity, Arab. J. Chem. 2014, 7, 1131-1139, http://dx.doi.org/10.1016/j.arabjc.2013.04.007. 
56. Raghunandan, D.; Bedre, M.D.; Basavaraja, S.; Sawle, B.; Manjunath, S.Y.; Venkataraman, A. Rapid biosynthesis of irregular shaped gold nanoparticles from macerated aqueous extracellular dried clove buds (Syzygium aromaticum) solution. Colloids Surf B Biointerfaces. 2010, 79, 235-240, https://doi.org/10.1016/j.colsurfb.2010.04.003.

57. Acharyulu, N.P.S.; Dubey, R.S.; Swaminadham, V.; Kalyani, R.L.; Kollu, P.; Pammi, S.V.N. Green synthesis of $\mathrm{CuO}$ nanoparticles using Phyllanthus amarus leaf extract and their antibacterial activity against multidrug resistance bacteria. Int.J. Eng. Res. Technol. 2014, 3, 639-641.

58. Senthilkumar, S.R.; Sivakumar, T. Green tea (Camellia sinensis) mediated synthesis of zinc oxide $(\mathrm{ZnO})$ nanoparticles and studies on their antimicrobial activities. Int J Pharm Pharm Sci. 2014, 6, 461-465.

59. Kalaiselvi, A.; Roopan, S.M.; Madhumitha, G..; Ramalingam, C.; Elango, G. Synthesis and characterization of palladium nanoparticles using Catharanthus roseus leaf extract and its application in the photo-catalytic degradation, Spectrochim Acta A Mol Biomol Spectrosc. 2015, 135, 116-119, https://doi.org/10.1016/j.saa.2014.07.010.

60. Herrera-Becerra, R.; Zorrilla, C.; Rius, J.L.; Ascencio, J.A. Electron microscopy characterization of biosynthesized iron oxide nanoparticles. Appl Phys A. 2008, 91, 241-246, https://doi.org/10.1007/s00339008-4420-7.

61. Ramimoghadam, D.; Bagheri, S.; Bee, S.; Hamid, A. Biotemplated synthesis of anatase titanium dioxide nanoparticles via lignocellulosic waste material. BioMed Res. Int. 2014, 2014, 1-7, https://doi.org/10.1155/2014/205636.

62. Sunkar, S.; Nachiyar, C.V. Biogenesis of antibacterial silver nanoparticles using the endophytic bacterium Bacillus cereus isolated from Garciniaxanthochymus. Asian Pac J Trop Biomed. 2012, 2, 953-959, https://doi.org/10.1016/S2221-1691(13)60006-4.

63. He, S.; Guo, Z.; Zhang, Y.; Zhang, S.; Wang, J.; Gu, N. Biosynthesis of gold nanoparticles using the bacteria Rhodopseudomonas capsulata. Mater Lett. 2007, 61, 3984-3987, https://doi.org/10.1016/j.matlet.2007.01.018.

64. Raliya, R.; Biswas, P.; Tarafdar, J.C. TiO2 nanoparticle biosynthesis and its physiological effect on mung bean (Vigna radiata L.). Biotechnol Rep. 2015, 5, 22-26, https://doi.org/10.1016/j.btre.2014.10.009.

65. Sanghi, R.; Verma, P. Biomimetic synthesis and characterisation of protein capped silver nanoparticles. Bioresour Technol. 2009, 100, 501-504, https://doi.org/10.1016/j.biortech.2008.05.048.

66. Khodakovskaya, M.; Dervishi, E.; Mahmood, M.; Xu, Y.; Li, Z.; Watanabe, F.; Biris, A.S. Carbon nanotubes are able to penetrate plant seed coat and dramatically affect seed germination and plant growth. ACS Nano, 2009, 3, 3221-3227, https://doi.org/10.1021/nn900887m.

67. Joshi, A.; Kaur, S.; Dharamvir, K.; Nayyar, H.; Verma, G. Multi-walled carbon nanotubes applied through seed-priming influence early germination, root hair, growth and yield of bread wheat (Triticum aestivum L.). J. Sci. Food Agri. 2018, 98, 3148-3160, https://doi.org/10.1002/jsfa.8818.

68. Banerjee, J.; Kole, C. Plant Nanotechnology: An overview on concepts, strategies, and tools. In Plant Nanotechnology; Kole, C., Kumar, D., Khodakovskaya, M., Eds.; Springer: Cham, Switzerland, 2016; 1-14.

69. Pokhrel, L.R.; Dubey, B. Evaluation of developmental responses of two crop plants exposed to silver and zinc oxide nanoparticles. Sci. Tot. Environ. 2013, 452, 321-332, https://doi.org/10.1016/j.scitotenv.2013.02.059.

70. Zheng, L.; Hong, F.S.; Lu, S.P.; Liu, C. Effect of nano-TiO2 on strength of naturally and growth aged seeds of spinach. Biol. Trace Elem. Res. 2005, 104, 83-91, https://doi.org/10.1385/bter:104:1:083.

71. Gopinath, K.; Gowri, S.; Karthika, V.; Arumugam, A. Green synthesis of gold nanoparticles from fruit extract of Terminalia arjuna, for the enhanced seed germination activity of Gloriosa superba. J Nanostruct Chem. 2014, 4, 1-11, https://doi.org/10.1007/s40097-014-0115-0.

72. Song, G.; Gao, Y.; Wu, H.; Hou, W.; Zhang, C.; Ma, H. Physiological effect of anatase TiO2 nanoparticles on Lemna minor. Environ. Toxicol. Chem. 2012, 31, 2147-2152, https://doi.org/10.1002/etc.1933.

73. El-Feky, S.A.; Mohammed, M.A.; Khater, M.S.; Osman, Y.A.; Elsherbini, E. Effect of magnetite nanofertilizer on growth and yield of Ocimum basilicum L. Int. J. Indig. Med. Plants.2013, 46, 1286-1293.

74. Prasad, T.N.V.K.V.; Sudhakar, P.; Sreenivasulu, Y.; Latha, P.; Munaswamy, V.; Reddy, K.R.; Sreeprasad, T.S.P.; Sajanlal, R.; Pradeep, T. Effect of nanoscale zinc oxide particles on the germination, growth and yield of peanut. J Plant Nutr. 2012, 35, 905-927, https://doi.org/10.1080/01904167.2012.663443.

75. Ramesh, M.; Palanisamy, K.; Babu, K.; Sharma, N.K. Effects of bulk \& nano-titanium dioxide and zinc oxide on physiomorphological changes in Triticum aestivumLinn. J Glob Biosci.2014, 3, 415-422. 
76. Servin, A.; Elmer, W.; Mukherjee, A.; De la Torre-Roche, R.; Hamdi, H.; White, J.C.; Bindraban, P.; Dimkpa, C. A review of the use of engineered nanomaterials to suppress plant disease and enhance crop yield. J.Nanopart. Res. 2015, 17, 92-113, https://doi.org/10.1007/s11051-015-2907-7.

77. Dwivedi, S.; Saquib, Q.; Al-Khedhairy, A.A.; Musarrat, J. Understanding the role of nanomaterials in agriculture. In Microbial Inoculants in Sustainable Agricultural Productivity; Singh, D.P., Singh, H.B., Prabha, R., Eds.; Springer: New Delhi, India, 2016; 271-288.

78. Sadak, M.S. Impact of silver nanoparticles on plant growth, some biochemical aspects, and yield of fenugreek plant (Trigonella foenum-graecum).Bull Natl Res Cent. 2019, 43, 38, https://doi.org/10.1186/s42269-0190077-y.

79. Stadler,T.; Buteler, M.; Weaver, D.K. Nover use of nanostructured alumina as an insecticide. Pest Manag.Sci. 2010, 66, 577-579, https://doi.org/10.1002/ps.1915.

80. Onaga, G.; Kerstin, W. Advances in plant tolerance to biotic stresses. In Plant Genomics; Abdurakhmonov, I.Y., Ed.; InTech: Rijeka, Croatia, 2016; 167-228

81. Siddiqui, M.H.; Al-Whaibi, M.H. Role of nano-SiO2 in germination of tomato (Lycopersicum esculentum seeds Mill.). Saudi J. Biol. Sci. 2014, 21, 13-17, https://doi.org/10.1016/j.sjbs.2013.04.005.

82. Wang, S.H.; Wang, F.Y.; Gao, S.C. Foliar application with nano-silicon alleviates Cd toxicity in rice seedlings. Environ. Sci. Pollut. Res. 2015, 22, 2837-2845, https://doi.org/10.1007/s11356-014-3525-0.

83. Iqbal, M.; Raja, N.I.; Hussain, M.; Ejaz, M.; Yasmeen, F. Effect of silver nanoparticles on growth of wheat under heat stress. IJST A Sci. 2019, 43, 387-395, https://doi.org/10.1007/s40995-017-0417-4.

84. Vanti, G.L.; Nargund, V.B.; Basavesha, K.N.; Vanarchi, R.; Kurjogi, M.; Mulla, S.I.; Tubaki, S.; Patil, R.R. Synthesis of Gossypium hirsutum-derived silver nanoparticles and their antibacterial efficacy against plant pathogens. Appl. Organomet. Chem. 2019, 33, e4630, https://doi.org/10.1002/aoc.4630.

85. Du,W.; Yang, J.; Peng, Q.; Liang, X.; Mao, H. Comparison study of zinc nanoparticles and zinc sulphate on wheat growth: From toxicity and zinc biofortification. Chemosphere. 2019, 227, 109-116, https://doi.org/10.1016/j.chemosphere.2019.03.168.

86. Rossi, L.; Fedenia, L.N.; Sharifan, H.; Ma, X.; Lombardini, L. Effects of foliar application of zinc sulfate and zinc nanoparticles in coffee (Coffea arabica L.) plants. Plant Physiol. Biochem. 2019, 135, 160-166, https://doi.org/10.1016/j.plaphy.2018.12.005.

87. Wang, Y.; Lin, Y.; Xu, Y.; Yin, Y.; Guo, H.; Du, W. Divergence in response of lettuce (var. ramosa Hort.) to copper oxide nanoparticles/microparticles as potential agricultural fertilizer. Environ. Pollut. Bioavailab. 2019, 31, 80-84, https://doi.org/10.1080/26395940.2019.1578187.

88. Dimkpa, C.O.; McLean, J.E.; Latta, D.E.; Manangón, E.; Britt, D.W.; Johnson, W.P.; Boyanov, M.I.; Anderson, A.J. $\mathrm{CuO}$ and $\mathrm{ZnO}$ nanoparticles: phytotoxicity, metal speciation, and induction of oxidative stress in sand-grown wheat. J Nano Res. 2012, 14, 1-15, https://doi.org/10.1007/s11051-012-1125-9.

89. Lahiani, M.H.; Dervishi, E.; Chen, J.H.; Nima, Z.; Gaume, A.; Biris, A.S.; Khodakovskaya, M.V. Impact of carbon nanotube exposure to seeds of valuable crops. ACS Appl. Mater. Interfaces. 2013, 5, 7965-7973, https://doi.org/10.1021/am402052x.

90. Khodakovskaya, M.V.; Kim, B.; Kim, J.N.; Alimohammadi, M.; Dervishi, E.; Mustafa, T.; Cernigla, C.E. Carbon Nanotubes as Plant Growth Regulators: Effects on Tomato Growth, Reproductive System, and Soil Microbial Community. Small. 2013, 9, 115-123, https://doi.org/10.1002/smll.201201225.

91. Dhoke, S.K.; Mahajan, P.; Kamble, R.; Khanna, A. Effect of nanoparticles suspension on the growth of mung (Vigna radiata) seedlings by foliar spray method. Nanotechnol Dev. 2013, 3, 1-5, https://doi.org/10.4081/nd.2013.e1.

92. Imada, K.; Sakai, S.; Kajihara, H.; Tanaka, S.; Ito, S. Magnesium oxide nanoparticles induce systemic resistance in tomato against bacterial wilt disease. Plant Pathol. 2016, 65, 551-560, https://doi.org/10.1111/ppa.12443.

93. Shenashen, M.; Derbalah, A.; Hamza, A.; Mohamed, A.; El-Safty, S. Antifungal activity of fabricated mesoporous alumina nanoparticles against root rot disease of tomato caused by Fusarium oxysporium. Pest Manag. Sci. 2017, 73, 1121-1126, https://doi.org/10.1002/ps.4420.

94. Malandrakis, A.A.; Kavroulakis, N.; Chrysikopoulos, C.V. Use of copper, silver and zinc nanoparticles against foliar and soil-borne plant pathogens. Sci. Total Environ. 2019, 670, 292-299, https://doi.org/10.1016/j.scitotenv.2019.03.210.

95. Torney, F.; Trewyn, B.G.; Lin, V.S.Y.; Wang, K. Mesoporous silica nanoparticles deliver DNA and chemicals into plants. Nat. Nanotechnol. 2007, 2, 295-300, https://doi.org/10.1038/nnano.2007.108. 
96. Rad, S.J.; Naderi, R.; Alizadeh, H.; Yaraghi, A.S. Silver-nanoparticle as a vector in gene delivery by incubation. IRJALS. 2013, 02, 21-33.

97. Miller, J.B.; Zhang, S.; Kos, P.; Xiong, H.; Zhou, K.; Perelman, S.S.; Zhu, H.; Siegwart, D.J. Non-viral CRISPR/Cas gene editing in vitro and in vivo enabled by synthetic nanoparticle co-delivery of Cas9 mRNA and sgRNA. Angew. Chem. Int. Ed. Engl.2017, 56, 1059-1063, https://doi.org/10.1002/anie.201610209.

98. Mout, R.; Ray, M.; Tonga, G.Y.; Lee, Y.-W.; Tay, T.; Sasaki, K.; Rotello, V.M. Direct cytosolic delivery of CRISPR/Cas9-ribonucleoprotein for efficient gene editing. ACS Nano. 2017, 11, 2452-2458, https://doi.org/10.1021/acsnano.6b07600.

99. Zhang, X.; Zhang, J.; Zhu, Y. Chitosan/double-stranded RNA nanoparticles-mediated RNA interference to silence chitin synthase genes through larval feeding in the African malaria mosquito (Anopheles gambiae). Insect Mol. Biol. 2010, 19, 683-693, https://doi.org/10.1111/j.1365-2583.2010.01029.x.

100.Gaur, P.K.; Pal, H.; Puri, D.; Kumar, N.; Shanmugam, S.K. Formulation and development of hesperidin loaded solid lipid nanoparticles for diabetes. Biointerface Res. Appl Chem. 2020, 10, 47284733, https://doi.org/10.33263/BRIAC101.728733.

101. Galbraith, D.W. Nanobiotechnology-Silica breaks through in plants. Nat. Nanotechnol. 2007, 2, 272-273, https://doi.org/10.1038/nnano.2007.118.

102. Vijayakumar, P.S.; Abhilash, O.U.; Khan, B.M.; Prasad, B.L.V. Nanogold-loaded sharp-edged carbon bullets as plant-gene carriers. Adv. Funct. Mater. 2010, 20, 2416-2423, https://doi.org/10.1002/adfm.200901883.

103.Martin-Ortigosa, S.; Peterson, D.J.; Valenstein, J.S.; Lin, V.S.Y.; Trewyn, B.G.; Lyznik, L.A.; Wang, K. Mesoporous Silica Nanoparticle-Mediated Intracellular Cre Protein Delivery for Maize Genome Editing via LoxP Site Excision. Plant Physiol.2013,164, 537-547, https://doi.org/10.1104/pp.113.233650.

104.Demirer, G.S.; Zhang, H.; Matos, J.; Goh, N.; Cunningham, F.J.; Sung, Y.; Chang, R.; Aditham, A.J.; Chio, L.; Cho, M-J.; Staskawicz, B.; Landry, M.P. High Aspect Ratio Nanomaterials Enable Delivery of Functional Genetic Material Without DNA Integration in Mature Plants. Nat. Nanothechnol. 2018, 14, 456-464, https://doi.org/10.1038/s41565-019-0382-5.

105.Sanzari, I.; Leone, A.; Ambrosone, A. Nanotechnology in plant science: to make a long story short. Front. Bioeng. Biotechnol. 2019, 7, 120, https://dx.doi.org/10.3389\%2Ffbioe.2019.00120.

106. Raliya, R.; Franke, C.; Chavalmane, S.; Nair, R.; Reed, N.; Biswas, P. 2016. Quantitative Understanding of Nanoparticle Uptake in Watermelon Plants. Front. Plant Sci. 2016, 7, 1288, https://doi.org/10.3389/fpls.2016.01288.

107. Avellan, A.; Schwab, F.; Masion, A.; Chaurand, P.; Borschneck, D.; Vidal, V.; Rose, J.; Santaella, C.; Levard, C. Nanoparticle Uptake in Plants: Gold Nanomaterial Localized in Roots of Arabidopsis thaliana by X-Ray Computed Nanotomography and Hyperspectral Imaging. Environ Sci. Technol. 2017, 51, 8682-8691, https://doi.org/10.1021/acs.est.7b01133.

108.Chang, F.P.; Kuang, L.Y.; Huang, C.A.; Jane, W.N.; Hung, Y.; Hsing, Y.I.C.; Mou, C.Y. A Simple Plant Gene Delivery System Using Mesoporous Silica Nanoparticles as Carriers. J. Mater. Chem. B. 2013, 1, 52795287, https://doi.org/10.1039/c3tb20529k.

109.Etxeberria, E.; Gonzalez, P.; Bhattacharya, P.; Sharma, P.; Ke, P. C. Determining the size exclusion for nanoparticles in citrus leaves. HortScience 2016, 51, 732-737, https://doi.org/10.21273/HORTSCI.51.6.732.

110.Birbaum, K.; Brogiolli, R.; Schellenberg, M.; Martinoia, E.; Stark, W.J.; Gunther, D.; Limbach, L. No evidence for cerium dioxide nanoparticle translocation in maize plants. Environ Sci Technol. 2010, 44, 87188723, https://doi.org/10.1021/es101685f.

111.Lee, W.M.; An, Y.J.; Yoon, H.; Kweon, H.S. Toxicity and bioavailability of copper nanoparticles to the terrestrial plants mung bean (Phaseolus radiatus) and wheat (Triticum aestivum): plant agar test for waterinsoluble nanoparticles. NanomatEnviron. 2008, 27, 1915-1921, https://doi.org/10.1897/07-481.1.

112.Zhu, H.; Han, J.; Xiao, J.Q.; Jin, Y. Uptake, translocation, and accumulation of manufactured iron oxide nanoparticles by pumpkin plants. J. Environ. Monit. 2008, 10, 713-717, https://doi.org/10.1039/b805998e.

113.Kah, M.; Beulke, S.; Tiede, K.; Hofmann, T. Nanopesticides: state of knowledge, environmental fate, and exposure modeling. Crit Rev Environ Sci Technol. 2013, 43, 1823-1867, https://doi.org/10.1080/10643389.2012.671750.

114.Petosa, A.R.; Rajput, F.; Selvam, O.; Ohl, C.; Tufenkji, N. Assessing the transport potential of polymeric nanocapsules developed for crop protection. Water Res. 2017, 111, 10-17, https://doi.org/10.1016/j.watres.2016.12.030.

115.Brock, D.A.; Douglas, T.E.; Queller, D.C.; Strassmann, J.E. Primitive agriculture in a social amoeba. Nature. 2011, 469, 393-396, https://doi.org/10.1038/nature09668. 
116.Chartuprayoon, N.; Rheem, Y.; Ng, J.C.K.; Nam, J.; Chen, W.; Myung, N.V. 2013. Polypyrrole nanoribbon based chemiresistive immunosensors for viral plant pathogen detection. Anal. Methods. 2013, 5, 3497-502, https://doi.org/10.1039/C3AY40371H.

117.Lin, H-Y.; Huang, C-H.; Lu, S-H.; Kuo, I-T.; Chau, L-K. Direct detection of orchid viruses using nanorodbased fiber optic particle plasmon resonance immunosensor. Biosens. Bioelectron. 2014, 51, 371-78, https://doi.org/10.1016/j.bios.2013.08.009.

118.Safarpour, H.; Safarnejad, M.R.; Tabatabaei, M.; Mohsenifar, A.; Rad, F.; Basirat, M.; Shahryari, F.; Hasanzadeh, F. Development of a quantum dots FRET-based biosensor for efficient detection of Polymyxa betae. Can. J. Plant Pathol. 2012, 34, 507-515, https://doi.org/10.1080/07060661.2012.709885.

119.Sharon, M.; Choudhary, A.K.; Kumar, R. Nanotechnology in Agricultural Diseases. J. Phytol. 2010, $2,83-$ 92.

120.Please replace this reference with this "Chaudhary, I.; Singh, V. Titanium dioxide nanoparticles and its impact on growth, biomass and yield of agricultural crops under environmental stress: A review. Res. J. Nanosci. Technol. 2020, 10,1-8, https://dx.doi.org/10.3923/rjnn.2020.1.8.

121.Boda, N.; Naidu, K.C.B.; MujasamBatoo, K.; Joice, G.H.R.; Naik, J.L.; Ravinder, D. Structural, morphological and electronic properties of cadmium cobalt ferrite nanoparticles. Biointerface Res. Appl Chem.2020, 10, 4752-4763, https://doi.org/10.33263/BRIAC101.752763.

122. Bergeson, L.L. Nanosilver pesticide products: What does the future hold?. Environ. Q. Manag. 2010, 19, 7382, https://doi.org/10.1002/tqem.20263.

123.Khot, L.R.; Sankaran, S.; Maja, J.M.; Ehsani, R.; Schuster, E. Application of nanomaterials in agricultural production and crop protection: a review. Crop Prot. 2012, 35, 64-70, https://doi.org/10.1016/j.cropro.2012.01.007.

124.Lin, D.; Xing, B. Phytotoxicity of nanoparticles : Inhibition of seed growth. Environ. Pollut. 2007, 150, 243250, https://doi.org/10.1016/j.envpol.2007.01.016.

125.Ruotolo, R.; Maestri, E.; Pagano, L.; Marmiroli, M.; White, J.C.; Marmiroli, N. Plant Response to MetalContaining Engineered Nanomaterials: An Omics- Based Perspective. Environ. Sci. Technol. 2018, 52, 24512467, https://doi.org/10.1021/acs.est.7b04121. 